\title{
Is Migration Good for an Economy? A Survey of the Main Economic Effects
}

Research article

Michael Frenkel

Chair of Macroeconomics and International Economics an der WHU - Otto Beisheim School of Management

Burgplatz 2, 56179 Vallendar

Received September 11 2017; Accepted October 92017

Abstract: This article surveys the main effects of labor migration between two countries. Against the background of high immigration to industrialized countries in recent years, notably to countries in Europe, the focus of the discussion is on the host country of the migrants. In the standard model of labor migration, there are overall benefits when wage differentials trigger labor migration. However, in the presence of externalities and deviations from the basic assumptions, the results can be significantly different.

Keywords: International migration • Production structure • International wage differentials

(C) De Gruyter Open Sp. z 0.0.

\section{Introduction}

Due to an increasing number of wars, the number of refugees worldwide has increased dramatically in the mid-2010s. According to the statistics of the United Nations High Commissioner for Refugees (UNHCR), more than half of the 17 million refugees in 2016 came from the wars in Afghanistan (5.5 million), Syria (2.5 million), and South Sudan (1.4 million). For several years already, countries not belonging to the group of highincome countries have hosted the bulk of the refugees. For example, in 2016, the top hosting countries were Turkey (2.9 million), Pakistan (1.4 million), Lebanon (1.0 million), Iran (1.0 million), Uganda (0.9 million), and Ethiopia (0.8 million). Among the high-income countries, the European Union (EU) countries saw a strong influx of refugees. Germany is the country that hosted more refugees than any other EU country, both in absolute terms and relative to its population. In 2015 alone, roughly 1 million refugees arrived in Germany.
The substantial increase in the number of refugees and other immigrants to several EU countries in the mid2010s has triggered an intense discussion about the economic cost and benefits of such flows. While many argue that refugees impose a financial burden on the economy that hosts them, some counter that the immigrants also offer a great opportunity for future economic growth. They stress that most of the refugees are very young and at the beginning of their work life. The argument about the young age of refugees is in accordance with the data published by the UNHCR, according to which more than half of the refugees worldwide are younger than 18 years of age.

Against this background, it appears worthwhile to examine the economic effects of immigration. However, the ultimate assessment of immigration should take into account more than economic factors and may well include ethical and humanitarian considerations. Nevertheless, examining the economic effects separately, 
which is the topic of this survey, can help clarify the arguments in the debate about immigration. When economic effects of migration are considered, we can distinguish between microeconomic and macroeconomic effects. The former include the cost-benefit considerations related to the migrants, while the latter focus on the economy of the home country or of the host country of the migrants as a whole. As the debate in the second decade of this century has become very controversial in industrialized countries as host countries, this study surveys the effects of immigration with a strong focus on the host country. Typically, such analyses examine labor market effects, fiscal effects, welfare effects, and growth effects. ${ }^{1}$

The remainder of the paper is structured as follows: Section 2 explains the economic effects of migration based on a simple framework of labor movement between two countries. Section 3 examines the effects of several deviations from the assumptions of the basic analysis. Section 4 briefly highlights that there are effects other than economic ones that an assessment of immigration can take into account. Section 5 summarizes the results and presents some conclusions.

1 See Hatton (2014) for a brief discussion of the topics that have shaped the debate on the effects of immigration.

\section{Basic Analysis of the Effects of Migration}

We begin our analysis by examining a very simple framework. ${ }^{2}$ We consider two countries, A and D, and the production of one good. The production uses labor, which we assume to be homogeneous and mobile between the two countries. For simplicity, we refer to the other factor of production as capital, but we could also include land in this category. ${ }^{3}$ We assume that capital is fixed and immobile. When owners of capital use more labor, the marginal product of labor diminishes. In this framework, wage differentials are the only factor determining migration, and there are no costs of migration. In Figure 1, the $\mathrm{MPL}_{\mathrm{A}}$ curve shows the marginal product of labor in country $A$ and $M P L_{D}$ shows the corresponding

2 Basic analyses similar to the one presented in this section can be found in Krugman et al. (2015) and Feenstra and Taylor (2017). A seminar paper on early studies on labour migration goes back to Stark and Bloom (1985), who explain the main theoretical and empirical issues, emphasizing that the vast majority of the work at the time was on migration within and from developing countries.

3 Here, we exclude the effects on economic growth. Refer Bodvarsson and Van den Berg (2013) for a discussion of how immigration can affect economic growth and Peri (2012), for the effects of immigration on total factor productivity.

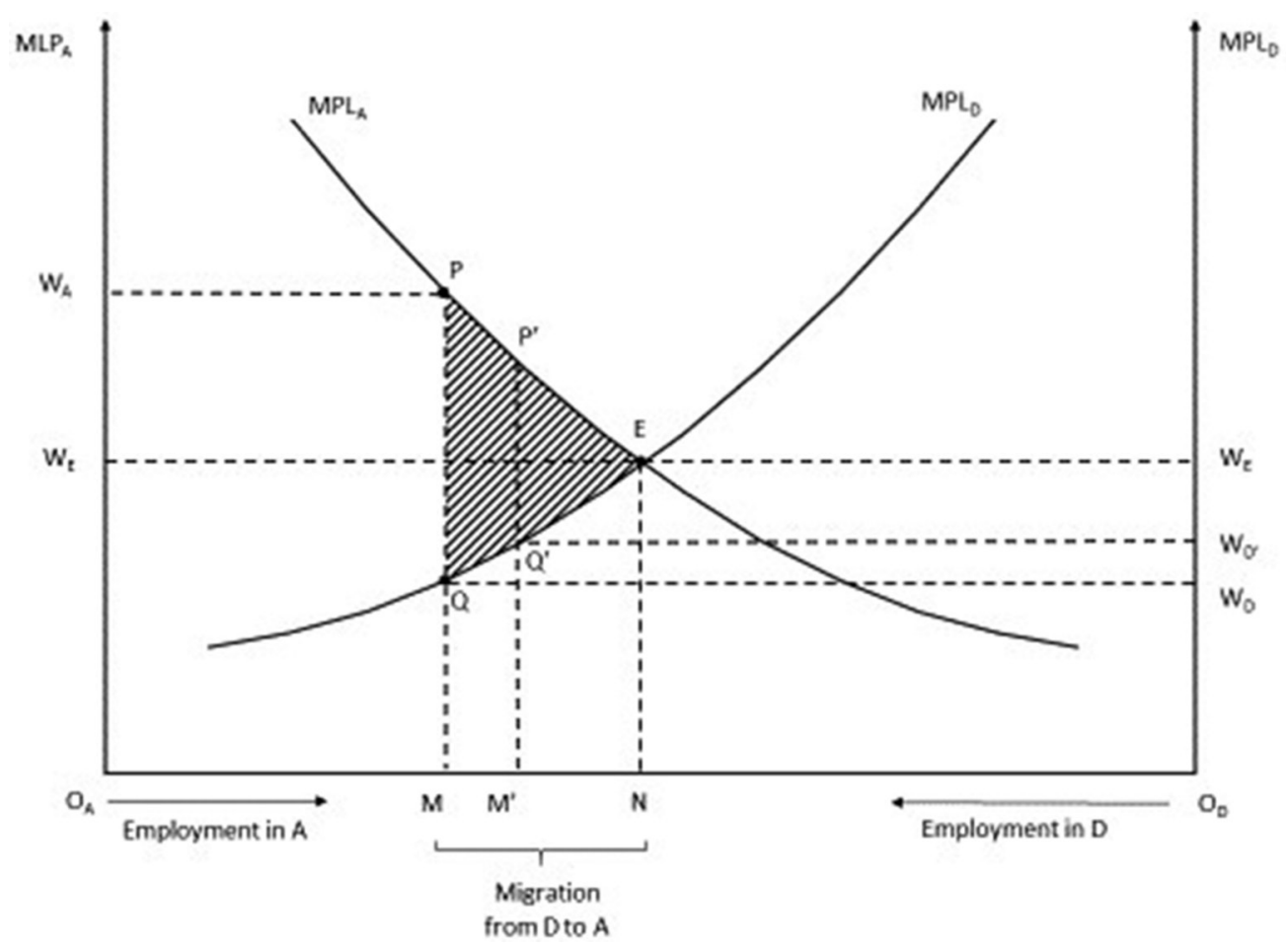

Figure 1. Wage Differentials and Migration 
curve for country D. In order to consider migration from a developing economy to an advanced economy, the graphs of the marginal product of labor would need to be different between the two countries. However, for simplicity we use similar graphs in Figure 1. In the initial situation, $\mathrm{O}_{\mathrm{A}} \mathrm{M}$ workers are employed in country $\mathrm{A}$ and $\mathrm{MO}_{\mathrm{D}}$ workers in country $\mathrm{D}$. The total labor force of the two countries combined is $\mathrm{O}_{A} \mathrm{O}_{D}$. Obviously, in country $\mathrm{D}$, the wage rate $w_{\mathrm{D}}$ is lower than the wage rate $w_{\mathrm{A}}$ in country $A$. If migration is not restricted, the difference $P Q$ will incentivize workers to migrate from country $D$ to country A.

As workers migrate, the wage rate in country A will decline, while it will increase in country D. Migration will come to a stop once the wage rates are the same. This is the case when MN workers leave country $D$ and migrate to country $A$; then, the wage rate is $w_{E}$ in both countries. Wage equalization stops migration and, thus, the labor structure changes to $\mathrm{O}_{\mathrm{A}} \mathrm{N}$ workers in the production of country $A$ and $\mathrm{NO}_{D}$ workers in country $\mathrm{D}$.

Moving from the initial situation to the equilibrium in $E$ is associated with a change in output in the two countries. Output in country $D$ decreases by the area QMNE, while output in country $A$ increases by the area PMNE. Hence, the world as a whole gains, as world output increases by the area of the triangle PQE. However, there will be losers, too. Workers in country A who originally earned $w_{\mathrm{A}}$ will receive a lower wage rate. This explains why workers in the host country who directly compete with the immigrants typically tend to oppose immigration. However, the owners of capital in country $A$ gain because their factor uses more labor after immigration. By contrast, in country D, owners of capital will earn less, as they use less labor on their land. As production in country $A$, which experiences immigration, rises less than proportionately compared to labor input, per capita income in country A decreases. By contrast, per capita income in country $D$ rises.

The analysis shows that the world as a whole gains from migration. Without any intervention, there will be winners and losers. In the host country of the migrants, workers lose and owners of capital gain. In the home country of the migrants, workers gain and owners of capital lose. This result resembles in its nature the effects of specialization and international trade. As the gains of the winners exceed the occurring losses, everybody in this simple framework could be made better off. However, this requires redistribution between the winners and the losers. For the migrants, who in this framework find employment in the host country, the effects are positive.

\section{Extensions of the Basic Analysis}

\subsection{Imperfections in the Labor Market: Unemployment}

The simple analysis described herein requires modification if imperfections prevail in the initial situation so that labor markets do not clear. If, e.g., wage rigidities lead to a wage rate of $w_{D^{\prime}}$ in country $D$, there will be unemployment equaling $\mathrm{MM}^{\prime}$. Considering that the unemployed workers migrate and constitute a share of the migrants to country $A$, the rise in world output is higher because the migrants do not reduce output in the home country $D$. In Figure 1, the additional output gain is the area QMM'Q'. The effect in the host country $A$ is the same as before. Thus, migration can mitigate certain imperfections.

\subsection{Worker Remittances}

A typical phenomenon associated with immigrants is that they transfer part of their income back to their families and friends in their home country (World Bank, 2016). In this case, national income in the home country of the immigrants does not fall as much, and national income in their host country does not expand as much as in the basic analysis. This implies that per capita income in the host country (country A in Figure 1) declines beyond the level shown in the basic scenario. For some home countries that have experienced significant emigration, remittances have indeed developed into a significant balance of payments item. Countries for which such international transfers are of high relevance include the Philippines, India, Mexico, the Caribbean, China, Morocco and Bangladesh. In these cases, such flows account for a significant share in total income for the home country and are, thus, welfare increasing.

Whether such remittances lead to long-term economic growth in the home country of the migrants depends on their use. Studies on this topic show that remittances typically flow into developing countries, and that the recipients mostly use them for consumption and not for investment. Papademetriou and Martin (1991) present early studies with relatively limited effect on economic growth in the home countries of the migrants. More recently, Bodvarsson and Van den Berg (2013) confirm these results and emphasize that the multiplier effects of additional consumption in the recipient countries are also not very high either. In many cases, this is mainly due to the lack of investment opportunities, which limits the secondary effects. 


\subsection{Effects of Migration on the Production Structure}

Migration also has effects on the production structure in the home and the host countries of the migrants. In order to examine such effects, we now introduce a second good and distinguish between a labor-intensive good and a capital-intensive good. We assume that country $A$ is a capital-abundant country and country $D$ is a labor-abundant country. In this respect, country $A$ could represent an advanced economy and country $D$ a developing country. In a Heckscher-Ohlin world, this leads to the following production and trade situation: the capital-abundant country A exports the capital-intensive good and imports the labor-intensive good. Likewise, country $D$ exports the labor-intensive product. Figure 2 shows the effects of migration of labor on the host country $\mathrm{A}$. Initial production is in $\mathrm{C}$, with the tangent line showing the relative price of the capital-intensive good. The steeper this tangent line is, the higher is the price of the capital-intensive good.

When workers migrate from country $D$ to country $A$, the immediate effect is an increase in the labor force in country A. This shifts the production possibility frontier outwards, and it will increase the maximum output of the labor-intensive good by more than the maximum output of the capital-intensive good. With fixed capital, output in both industries is likely to rise (point G). This will likely be the case in the short term, and it causes relative factor price changes as described in the basic analysis. However, if capital is also mobile between the two sectors, the Rybczynski theorem suggests that the increase of labor leads to an increase in the production of the labor-intensive good so that the capital-abundant country experiences an expansion of the labor-intensive production and a contraction of the capital-intensive good. Production shifts from $\mathrm{C}$ to $\mathrm{C}^{\prime}$. In this case, immigration to the capital-abundant country has the opposite effects as international trade in goods. Hence, the strong immigration in 2015 to advanced economies, notably to the ones in Europe, could therefore change the production structure towards more labor-intensive goods.

In Figure 2, the tangent line through $C^{\prime}$ is parallel to the tangent line through $\mathrm{C}$. This is the outcome if only production parameters affect the new production structure and there is no influence of demand changes and international price changes. Then, in the extreme case, the price ratio and the factor intensities remain unchanged and so does the factor price ratio. This means that the change in the production structure absorbs the increase in labor endowment caused by

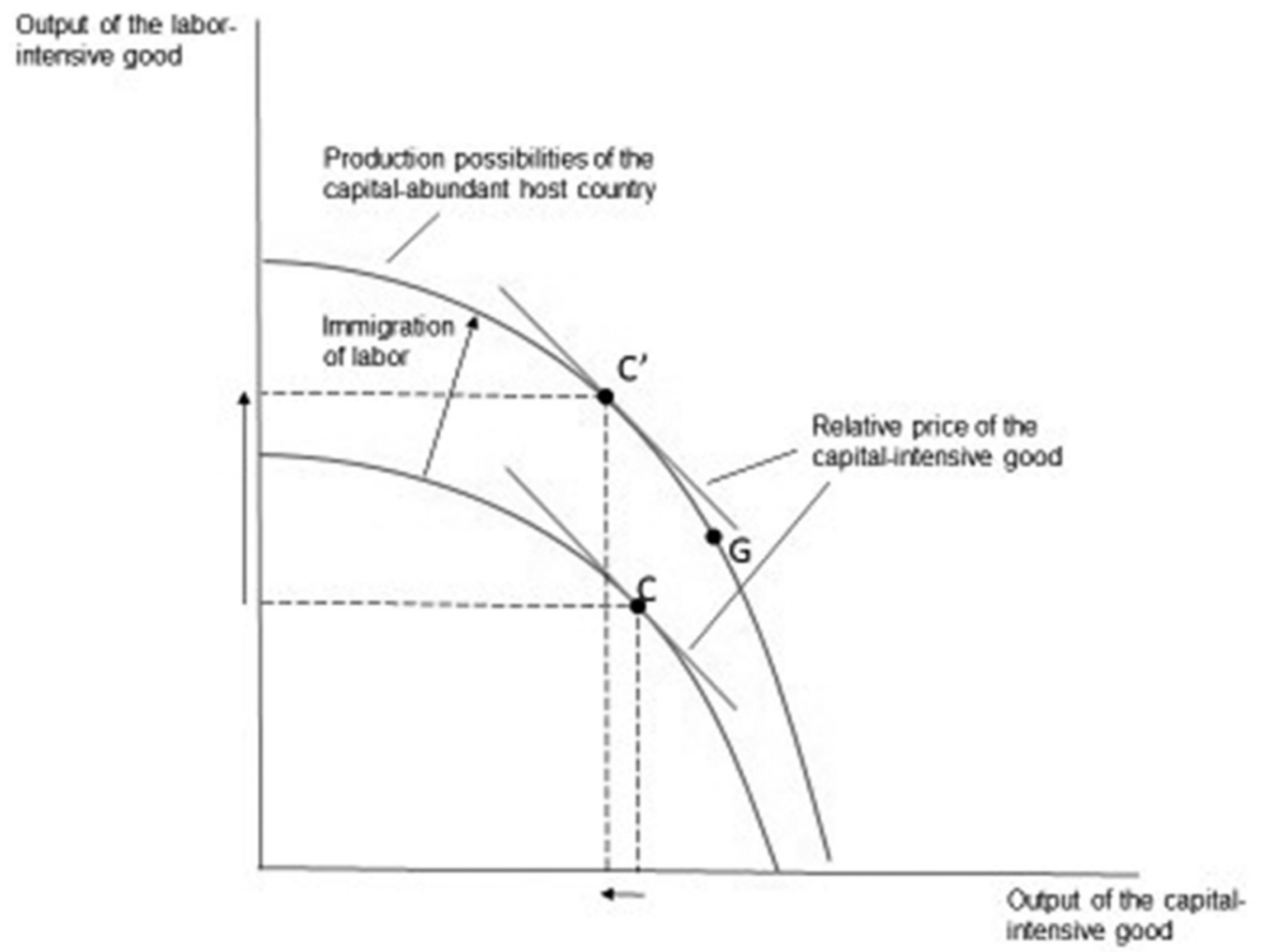

Figure 2. Immigration and Production Structure 
immigration. Consider, for instance, the case in which the labor endowment in both industries is 100 units and the capital endowment in the production of the laborintensive good is 10 units and in the production of the capital-intensive good is 40 units. Hence, labor intensity in the production of the labor-intensive good is 10 $(=100 / 10)$ and it is $2.5(=100 / 40)$ in the production of the capital-intensive good. Now, assume that there is an influx of labor of 30 units. If the entire increase in the labor force is used in the production of the laborintensive good, capital income will rise in this sector, attracting capital from the capital-intensive sector to shift to this industry. If - as can be expected - capital is mobile in the long term, then capital will shift towards the labor-intensive sector. Some additional labor shifts to the labor-intensive sector as well and - in case no other factors influence the price ratio between the two goods - there will be 140 units of labor in the production of the labor-intensive product together with 14 units of capital. Likewise, there will be 90 units of labor in the capital-intensive production together with 36 units of capital. Both sectors have the same labor intensity as before (in the labor-intensive sector, it is 140/14 $=10$ and in the capital-intensive sector, it is 90/36 $=2.5$ ). In this case, factor prices will not change. This suggests that, in the absence of any demand effects, distortions, and changes in international prices, the pure consideration of the production technology does not necessarily require factor prices to change in the end. ${ }^{4}$ However, if the outcome of immigration is also a relative rise in the demand for the capital-intensive good, then the relative price of capital will rise, which is accompanied by a change in the production structures. In this case, the described output decline of the capital-intensive good will not occur and the relative price of labor will fall. This effect is in accordance with the predictions of the Stolper-Samuelson theorem.

\subsection{Heterogeneous Labor}

The assumption of homogeneous labor does not appear very realistic, as skill levels differ widely between countries. In order to capture this aspect, we now extend the simple framework by assuming that labor is heterogeneous, i.e., there are different skill levels of labor. This is particularly relevant when examining migration between developing countries and advanced countries. In fact, this was an important issue in the context of the strong influx of immigrants to advanced economies in Europe in 2015. We distinguish here between two types of labor,

4 Refer also Dustmann et al. (2008). skilled and unskilled. When migration takes place from developing to advanced economies, migrants may have predominantly lower skills, although this is not necessarily the case. Let us assume that the host country of the migrants is again an advanced economy, i.e., in the context we analyze now, it is a country with a high share of skilled labor. Likewise, we assume that the home country of the migrants is a developing country, i.e., it has a high share of unskilled labor. The effects then follow our previous analysis. Wages of unskilled labor rise in the home country and decline in the host country, where this factor becomes more abundant in production. Output declines in the home country and increases in the host country. Wages of skilled labor in the advanced economy tend to rise because this factor uses more unskilled labor. The decline in wages of unskilled labor in the host country as predicted in this framework can again explain why opposition to immigration is especially high among workers with low skill levels. This was the case when European countries experienced strong immigration in 2015 from Afghanistan, Syria, Iraq, and Northern Africa. A number of empirical papers have studied the wage effect of immigration outlined here by distinguishing different wage categories. Several of them investigate the effects on wages of unskilled and wages of skilled workers (Altonji and Card 1991; Card 2001, 2005; Friedberg 2001; Borjas 2003; Dustmann et al. 2005; Jaeger 2007). Other studies analyze the effects on relative wages (Card and Lewis 2007; Glitz 2012; Manacorda et al. 2012; Ottaviano and Peri 2012). While most of the results confirm the qualitative results outlined herein, the quantitative results differ considerably.

Dustmann et al. (2013) point out an additional interesting cause of the described wage effect in different skill categories. They find that immigrants downgrade upon arrival, independent of their skill level. This downgrading results from the immigrants not being able to use their educational background completely when searching for a job. This inability can result from language and cultural barriers. In this case, immigration depresses wages in the lower part of the wage distribution and increases wages in the upper part of the wage distribution even if the distribution of qualifications of immigrants is the same as that of native workers. ${ }^{5}$ The empirical study for the UK suggests that this effect lasts for 2 years.

Dustman et al. (2013) also see the initial downgrading or mismatch as contributing to their empirical finding that immigration has slightly increased the average wages in the UK: an initial mismatch or downgrading causes a lower payment to immigrants than their true

5 Eckstein and Weiss (2004) find similar results for Israel. 
marginal product amounts to and, thus, natives can benefit from this. This argument is different from the "grease the wheels" explanation of Borjas (2001), who emphasizes that immigration may reduce labor market rigidities and therefore lead to efficiency gains reflected in higher average wages. However, the problem with this argument is that immigrants would capture the benefits of the efficiency increases, which is in contrast to the empirical evidence, unless one argues that the efficiency gains result from the pressure of immigrants in the labor markets, but the natives capture the benefits.

What are the effects if there is immigration of skilled labor rather than unskilled labor? In essence, we can apply the results of the previous analysis of the immigration of unskilled workers. This means that wages of unskilled labor rise in the host country because of the rise in productivity of this factor resulting from more intensive use of skilled labor. Likewise, in the home country of the migrants, wages of unskilled labor declines. Wages of skilled labor decline in the host country and rise in the home country. The empirical study of Docquier et al. (2014) confirms this result. ${ }^{6}$ In the theoretical framework, this implies that output declines in the home country and increases in the host country. This explains why the opposition to immigration is likely to come more from skilled workers. Nevertheless, the empirical evidence is that this type of opposition has been rather small. This may have to do with the fact that skilled workers do not feel particularly threatened. A longer-term effect from the immigration of skilled labor on the host country is the growth effect resulting from this type of migration. If immigrants are highly skilled and bring new ideas to the host country, they can engage in entrepreneurial activities and, thereby, stimulate economic growth. Whether this is indeed a strong effect is still an open debate.

For the home country of the skilled workers, the effects can be particularly negative if skilled workers are very scarce in the home country, as in the case of developing countries. The associated brain drain lets output and per capita income fall more significantly than is the case with unskilled labor. In addition, income inequality between advanced and developing countries increases further. If this factor of production is also very important for the entrepreneurial spirit in the business sector, which leads to product and process innovation, this brain drain in the home country of the immigrants

6 Their study examines labour migration between Organisation for Economic Co-operation and Development (OECD) countries. They find that the share of immigrants with a college degree who come from OECD countries is typically higher than the share among natives. In some cases, this share is even much higher than the share among natives. induces effects on economic growth, too. This explains why governments sometimes tend to restrict emigration, especially in developing countries. However, governments may find it counterproductive to implement such restrictions. This is the case because such restrictions may reduce the incentives for education and acquiring skills in these countries, since the expectation to find a well-paid job abroad afterwards may lead to more education. If this is the case, open borders, i.e., giving the possibility to emigrate, may lead to a brain gain by creating incentives to invest in education. A decline in such incentives is not in the interest of governments of developing countries or more generally of those countries where emigration takes place intensely.

Brain drain has been an important issue in economic development in some parts of the world. Eastern European countries lost a significant share of their skilled labor after they became members of the EU and the EU extended labor mobility to these countries. A more significant effect occurred in the Caribbean. As shown by Mishra (2006), the countries in the Caribbean lost between $10 \%$ and $40 \%$ of their labor force to Organisation for Economic Co-operation and Development (OECD) countries during the period 1970-2000. Many of the emigrants were well educated and several of these countries lost the majority of their highly skilled labor. Although the Caribbean countries experience high worker remittances amounting to an average of $13 \%$ of their GDP, the income loss following the brain drain was the dominating welfare effect. ${ }^{7}$

\subsection{Lack of Integration}

If workers of country $D$ migrate to country $A$, but not all of them find employment, then also the results are different from those of the basic analysis. The reasons for migrating and not finding a job can be manifold. The migrants may leave their home country because of external shocks that reduce their quality of life, but they may not find employment in the host country due to an economic downturn in the host country or because of a lack of skills. The latter may have to do with lowerthan-required skill levels, lack of work experience, and cultural differences (including language capabilities). In this case, output in country $A$ rises by a lesser amount compared to that in the basic analysis, and the overall gains are smaller and could possibly even disappear. As a result, the decline in per capita income in country $A$ is higher. The extent to which migrants nevertheless may stay in the host country or return to their home country

7 Dawson (2007) also presents a study of the brain drain in the Caribbean. 
then depends on microeconomic factors, i.e., on their weighing of the cost and benefits of the alternatives.

The negative effects will be higher if the lack of integration leads to frictions in the society in the form of destabilization of public life and cultural clashes. Such effects are difficult to anticipate, but opponents of immigration often emphasize these effects.

Empirical evidence supports the view that integration of immigrants can take a long time. The OECD (2017) shows that in Europe, unemployment among immigrants is significantly higher than among natives. Moreover, in examining the past decades, the OECD finds that it has taken immigrants $15-20$ years to reach a comparable employment level as natives.

\subsection{Taking into Account the Welfare State with Taxes, Social Transfers, Integration Cost, and Publicly Provided Goods}

An important consideration of the economic effects of migration results from the fact that advanced economies typically include elements of a welfare state. This implies that the analysis needs to take into account the effects of taxes, social transfers, and publicly provided goods. In a number of areas in the economy, state intervention leads to a change of the economic outcomes. Let us start, e.g., with unemployment benefits. In order to mitigate the effects of unemployment, the welfare state regularly provides support for the unemployed through a public insurance scheme. Unskilled labor is typically more prone to individual economic instability than skilled labor. Hence, migration of unskilled labor increases the absolute and relative number of those that bear the consequences of such instability. This implies that government expenditure tends to rise with more immigration of unskilled labor. To finance the respective programs, governments may raise, for instance, taxes on labor and/or capital income. However, this leads to higher taxes on even the unskilled native workers of the host country. Hence, the higher the share of unskilled labor in total immigration, the higher can be such externalities and the lower are the gains from migration.

The analysis of the effects of immigration requires similar modification if other elements of the welfare state are taken into account. In general, the welfare state leads to a redistribution of income from households with relatively high income to those with relatively low income. Moreover, those with higher income pay more for publicly provided goods than those with low income. As a result, those with relatively high income tend to be net payers into the public budget, while those with relatively low income tend to receive a higher value of benefits compared to what they contribute with their own income. If immigrants have predominantly low incomes, this causes an effect that a complete analysis would have to take into account.

These considerations suggest that in a welfare state, the question of whether immigration leads to more benefits or cost to the host country is not just a question of whether or not the immigrants find employment. Instead, the answer depends on whether or not the immigrants pay more into the entire welfare system than they receive from the system, not only in terms of social transfers, but also in the form of publicly provided goods, including education, health care, and integration support. A sensible analysis would also have to assess the described fiscal effects over the entire time span that the immigrants stay in the host country. Such an analysis is also relevant when looking at the effects of immigrants on the demographics in the host country. Then, the net position of the future generation of the immigrants becomes important, too.

Taking into account the fiscal considerations suggests that it is possible that the economic effects of immigration on the income of the native workers can be negative. While immigrants can generate positive economic effects for some factors of production of the host country, they may cause net cost for the welfare system. Hence, it is possible that such cost will more than offset the benefits generated in the production of private goods. If this is the case, the overall economic effects for the natives of the economy are negative, although the microeconomic analysis could still point to positive effects for the immigrants.

There are different possibilities for host countries to mitigate or avoid the risk of net negative macroeconomic effects of immigration. One possibility is to charge an immigration tax, which reduces the microeconomic benefits of immigration and offsets possible negative effects on the natives (Bhagwati 1979). The risk of net negative effects from immigration also forms the basis for the proposal to make the permission to immigrate conditional upon fulfilling certain criteria. For example, a host country could decide to make immigration dependent on language skills, qualifications, and work experience of applicants. In addition, the host country could apply conditions on the age of immigrants in order to generate more gains, especially when migration is permanent. Some countries indeed have immigration laws that combine such considerations in a point system, on the basis of which an individual qualifies for immigration or not. Australia and Canada are the best-known examples of such a point system. ${ }^{8}$

8 Hollifield et al. (2014) compare the immigration policies and outcomes of major industrialized countries. 
Does immigration of skilled labor generate better economic results? The analysis herein suggests that a high share of skilled labor among immigrants increases the probability that economic effects for the host country are positive, particularly when the effects resulting from the welfare state are taken into account. This explains why the empirical evidence points towards less restrictive immigration rules when it comes to skilled labor.

Against this background, the immigration to Europe from Afghanistan, the Middle East, and Northern Africa in the mid-2010s raised concerns that such influx is associated with higher cost than benefits. Applying the arguments outlined in the previous sections, immigration from these countries can lead to high benefits if the immigrants are young, if they arrive with high levels of education including language capabilities, and if their integration into the labor market and the society is relatively easy. Empirical work supports the results of the analysis. Dustmann and Frattini (2013) estimate that immigration into the UK between 1995 and 2012 had positive net effects on the welfare system. A study by the OECD (2013) surveys the different methodologies applied in estimating the fiscal effects of immigration and estimates the fiscal effects of immigrants in different countries. The OECD finds a large variety of net fiscal effects of immigrants and attributes this mainly to the composition of the immigrants. Skill levels and age, as well as the business cycle, seem to play an important role in determining the net benefits and net cost of immigration. Applying a generation accounting framework, Raffelhüschen and Moog (2016) emphasize the importance of these factors and estimate the future effects of immigration to Germany. According to their estimates, the budgetary effects of the immigration wave into Germany, which experienced a peak in 2015 , is unambiguously negative, i.e., immigration will be a drain on the government resources, requiring higher taxation of about $2 \%$ points over the current tax burden.

\section{From Economics to Ethics}

Economic effects are just one group of arguments when thinking about and assessing immigration. Ethical questions about immigration and citizenship have also triggered an intense discussion among social scientists, political theorists, and philosophers. This discussion is not the topic of this survey, and this section merely points to the importance of a very different line of arguments.

While some time ago, there was a consensus about the right of a country to safeguard its borders and keep foreigners out, there is less of a consensus on this position nowadays (Pevnic 2009). The induced discussion often deals with the question of what would be acceptable reasons to deny the citizenship to individuals (Cole 2000). Put differently, what does justice necessitate and what does it allow and forbid, when it comes to immigration in modern democratic countries? Such questions arise not only when individuals want to immigrate, but also when they have already entered the country and states have to decide how to treat them. The ethical questions are manifold and are partly interconnected. They clearly go beyond practical concerns of politics and deal with moral issues. As highlighted by Carens (2013), political commitments to fundamental democratic principles can constrain the answers to the related ethical questions. These democratic principles can include a number of broad issues, which include, e.g., the idea of fairness, the idea of equal moral value of all human beings, the idea that majority rules should solve disagreements, and the idea that all citizens of a country should get equal treatment under the law. They also include the idea that there should be no discrimination for racial, ethical, gender or religious reasons. The discussions often entail an interpretation of how states should interpret human rights and what their moral obligations are. Ultimately, ethical considerations depend on norms and are therefore normative.

Applying ethical considerations to the strong recent flow of immigrants to industrialized countries in 2015, notably to those in Europe, one may argue that there is a moral obligation to help those who flee from war in their home countries because the alternative scenario for them would entail high risk for their lives. Germany, with its history of having committed numerous atrocities in World War II and having caused millions of deaths and enormous destruction in many countries, may feel a particular responsibility to support refugees. However, even without such historical reasons, one may argue that states should tolerate immigration based on humanitarian reasons. On this basis, the cost that immigrants may cause for an individual country may not be the decisive factor in assessing immigration. This may particularly be the case when the host country can afford the financial burden.

Economic arguments indeed become less important if the assessment of immigration takes into account the duration of the stay of refugees. For example, if refugees from war-ridden countries spend only a limited time in the host country because they wait until it is safe for them to return to their home countries, immigration is not permanent but temporary. In this case, the question about the longer-term economic costs becomes less relevant and ethical considerations become more important. 


\section{Conclusions}

This article provides a survey of the main effects of migration, with a focus on the country into which immigration occurs. The basic economic analysis, which assumes homogeneous labor, shows that there can be overall benefits for the host country of the migrants, but that domestic workers lose. As the overall benefits exceed the cost for individual groups, there is a need for redistribution of gains from the winners to the losers. Just like in international trade, which also causes winners and losers with net benefits for an economy, such redistribution often does not happen systematically.

Once the analysis lifts some restrictive assumptions of the basic model, some positive and some negative effects come out more clearly. For example, if immigrants are primarily low-skilled workers, the group of low-skilled workers in the host country loses relative to the group of high-skilled workers. However, in this case, high-skilled workers in the host country benefit. Hence, negative economic effects for the group of workers with low skills become more likely when education

\section{References}

[1] Altonji J.G., Card D., The effects of immigration on the labor market outcomes of less-skilled natives, In: Abowd J.M., Freeman R.B. (Eds.), Immigration, trade and the labor market, University of Chicago Press, Chicago, 201-234, 1991.

[2] Bhagwati J.N., International migration of the highly skilled: economics, ethics and taxes, Third World Quarterly, 1, 17-30, 1979.

[3] Bodvarsson Ö.B., Van den Berg H., The economics of immigration - theory and policy, SpringerVerlag New York, New York, 2013.

[4] Borjas G.J., Does immigration grease the wheels of the labor market?, Brookings Papers on Economic Activity, 69-119, 2001.

[5] Borjas G.J., The labor demand curve is downward sloping: reexamining the impact of immigration on the labor market, Q J Econ, 118, 1335-1374, 2003.

[6] Card D., Immigration inflows, native outflows and the local labor market impacts of immigration, J Labor Econ, 19, 22-64, 2001.

[7] Card D., Is the new immigration really so bad, Econ J, 115, F300-F323, 2005.

[8] Card D., Lewis E.G., The diffusion of Mexican immigrants during the 1990s: explanations and impact, In: Borjas G.J. (Ed.), Mexican immigration levels of immigrants are low. Low-skilled workers of the host country also experience more competition in case immigrants have work experience, relatively high age, and low language capabilities, as well as coming from countries with significant cultural differences relative to the host country of the immigrants. In all these cases, immigrants compete more with low-skilled workers in the labor market of the host country. Again, in all these cases, high-skilled workers benefit.

Of course, even if the economic effects of the influx of migrants in a particular situation do not support the expectation of overall net benefits, states may nevertheless adopt a positive attitude towards immigrants. This is the case if there are overriding ethical reasons, e.g., if immigrants are refugees and a state regards the support of such immigrants as its moral obligation. The influx of immigrants into Germany in 2015 may be an example in which the country may realistically expect low or no economic benefits but may adopt a more positive attitude towards immigration based on humanitarian reasons. to the United States, University of Chicago Press, Chicago, 193-228, 2007.

[9] Carens J.H., The ethics of immigration, Oxford University Press, Oxford, 2013.

[10] Cole P., Philosophies of exclusion: liberal political theory and immigration, Edinburgh University Press, Edinburgh, 2000.

[11] Dawson L.R., Brain drain, brain circulation, remittances and development: prospects for the Caribbean, The Centre for International Governance Innovation, Caribbean Paper No. 2, Waterloo, Canada, 2007.

[12] Docquier F., Ozden C., Peri G., Labour market effects of immigration and emigration in OECD countries, Econ J, 124, 1106-1145, 2014.

[13] Dustmann C., Glitz A., Frattini T., The labour market impact of immigration, CReAM (Center for Research and Analysis of Migration), Discussion Paper No. 11/08, 2008.

[14] Dustmann C., Frattini T., The fiscal effects of immigration to the UK, CReAM (Center for Research and Analysis of Migration), Discussion Paper No 22/13), 2013.

[15] Dustmann C., Frattini T., Preston I.P., The impact of immigration on the British labor market, Econ J, 115, F324-F341, 2005. 
[16] Dustmann C., Frattini T., Preston I.P., The effect of immigration along the distribution of wages, Rev Econ Stud, 80, 145-173, 2013.

[17] Eckstein Z., Weiss Y., On the wage growth of immigrants: Israel 1990-2000, J Eur Econ Assoc, 2, 665-695, 2004.

[18] Feenstra R.C., Taylor A.M., International economics, New York, 2017.

[19] Friedberg R.M., The impact of mass migration on the Israeli labor market, Q J Econ, 116, 1373-1408, 2001.

[20] Glitz A., The labor market impact of immigration: a quasi-experiment exploiting immigrant location rules in Germany, J Labor Econ, 30, 175-213, 2012.

[21] Hatton T., The economics of international migration: a short history of the debate, Labor Econ, 30 (Issue C), 43-50, 2014.

[22] Hollifield J., Martin P., Orrenius P., Controlling immigration: a global perspective, $3^{\text {rd }}$ ed., Stanford University Press, Redwood City, CA, 2014.

[23] Jaeger D.A., Skill differences and the effect of immigration on the wages of natives (mimeo, College of William and Mary), 2007.

[24] Krugman P.R., Obstfeld M., Melitz M.J., International economics, Pearson 10 th edition, Essex, 2015.

[25] Manacorda M., Manning A., Wadsworth J., The impact of immigration on the structure of male wages: theory and evidence from Britain, J Eur Econ Assoc., 10, 120-151, 2012.
[26] Mishra P., Emigration and brain drain, evidence from the Caribbean, IMF Working Paper No. 25/06, Washington, 2006.

[27] OECD., International migration outlook, OECD, Paris, 2013.

[28] OECD., International migration outlook, OECD, Paris, 2017.

[29] Ottaviano G.I.P., Peri G., Rethinking the effects of immigration on wages, J Eur Econ Assoc., 10, 152197, 2012.

[30] Papademetriou D.G., Martin P.L., (eds.)., The unsettled relationship: labor migration and economic development, Greenwood Press, Westport, CT, 1991.

[31] Peri G., The effect of immigration on productivity: evidence from US states, Rev Econ Stat, 94, 348358, 2012.

[32] Pevnic R., Social trust and the ethics of immigration policy, J Polit Philos, 17, 146-167, 2009.

[33] Raffelhüschen B., Moog S., Zur fiskalischen Dividende der Flüchtlingskrise: Eine Generationenbilanz, ifo Schnelldienst, 69 (4), 24-29, 2016.

[34] Stark O., Bloom D.E., The new economics of labor migration, Am Econ Rev, 75 (2), Papers and Proceedings, 173-178, 1985.

[35] World Bank., Migration and remittances, fact book 2016, $3^{\text {rd }}$ ed., World Bank, Washington, 2016. 